\title{
東京中心部における皇室御料地の形成過程 THE FORMING PROCESS OF THE IMPERIAL ESTATE IN CENTRAL TOKYO
}

\author{
三浦 涼*, 佐 藤 洋一** \\ Ryo MIURA and Yoichi SATO
}

\begin{abstract}
The purpose of this study is to clarify the forming process and the distribution of the Imperial Estates in central Tokyo since the Meiji Era, and to examine the importance of these lands in the formation of modern capital. The study is based on the investigation of documents and materials, and is mainly refered to the description on "Teishitsu-Rinyakyoku Gojunenshi" [fifty years history of Imperial Forestry Bureau]. First of all, we made the list of "the first category" of the Imperial Estate, mostly consisted with palaces, which existed in pre-war period in the central Tokyo. Secondly, we made the distribution map at 3rd, 14th and 23rd year of Meiji, 12th year of Taisho and 12th year of Showa Era, and analyzed its transition. Pointing out that the Imperial Estates had relations with the Europeanization of the capital at the middle of Meiji Era and the establishment of Scenic Zone and Aesthetic Zone, We examined the importance of the Imperial Estates in the urban history at Tokyo.
\end{abstract}

Keywords: Imperial property, Scenic Zone, Aesthetic Zone, Palace, Imperial land grarit, Modern urban history 皇室財産, 風致地区, 美観地区, 宮殿, 下賜地, 近代都市形成史

1.はじめに

\section{1-1. 研究の背景}

明治から昭和戦前にかけて、東京の各所に存在した皇室財産として の土地は、軍用地等と同様に、東京中心部においてかなりの範囲を占 有していたにも関わらず、市区改正計画や帝都復興計画といった「都 市計画」政策とは全く別の次元での発展をみ、独自の都市空間を形成 していった。つまり、東京の近代都市形成における計画的な土地の組 み替えは、いわゆる「都市計画」の範囲外においても様々な面で行わ れたわけであり、䈙ろこ机らによる都市の変容を読み込むことが、東 京の首都としての中心性や、或いは都市の近代化を確立していく過程 を理解する手段となり得るのではないかと考える。特に、王権および 軍事権力を一般の公的権力を上回る存在としてみ㥙ば、戦前における 東京の都市空間の実態を探る上で、これらが無視し難い位置にあると 捉えざるを得ない。

黒田りは、明治以降に設けられた皇室関倸の土地には、皇室財政を 豊かにする目的のみならず、皇室の権威・権力を保持する目的も含ま れていたという見解を示している。しかし一方では、明治期における 土地取得過程やその規模等からみると、これら皇室関係の土地の成立 には、王権力の介在によってはじめて可能となった側面をも見いだす ことができる。また、大正から昭和戦前期においては、風致地区や美
観地区といった諸法規と密接な関係を持ち、都市の景観においても重 要な存在となっていたことをみれば、皇室の権威は土地の形態面のみ ならず、都市内の空間的なデザイン面にまでも反映されるものであっ たと言える。

しかし今日において、一般的な東京の都市形成史を、これら皇室関 連の土地や軍用地を通して語ろうとするものは非常に少ない2)。特に 前者に関しては、不明瞭な点が多いだけでなく、戦後はイデオロギー 的な論争と結びつきやすいことによって、様々な面でタブー視されて きたこともあり、現在こ㧈らの事象を正面から捉えた学術的な研究は 皆無となっている。本研究では、皇室関連の土地が東京の都市形成史 上において一つの盲点となっていることを踏まえ、その中心的存在で ある皇室御料地についての基礎的な情報を収集整理するものである。 1-2. 関連する研究・研究の課題

本研究は(1)明治以降における東京の土地再編過程と、(2)天皇及び皇 室と都市との関係性に関する、双方の研究の交点に位置付けることが できる。まず(1)に関しては、特に鈴木 ${ }^{3)}$ 、陣内1)の著作と強い関連性 を有している。これらの著作には、明治以降の旧武家屋敷の軌跡と、 そ㧈によって形成さ扎た東京の近代都市空間に関する分析、記述をは じめ、「都市計画」政策の範囲外において変容を見せた部分に基づく 東京像の描写が見られる。一方、(2)に関しては同じく鈴木》の著作を
* 梓設計 修士(工学)

** 早稲田大学専門学校＼cjkstart講師・博士(工学)
Azusa Sekkei, M. Eng.

Lecturer, College of Technology, Waseda Univ., Dr. Eng. 
はじめ、古賀 ${ }^{6}$ 、伊東 ${ }^{7}$ の研究があげられる。鈴木は皇族邸を中心と した東京における皇室関連用地の形成過程に言及して打り、古賀と伊 東は風致地区・美観地区といった都市計画制度と天皇との関係性に関 して考察を行っている。

しかし、依然としてこれらの研究を以てしても明らかにされない歴 史的な事象は数多く、東京の都市形成過程はそれらを全て解明した上 で再考される必要があると思われる。そこで、皇室御料地に着目して この再考を行うには、まず以下のことを明らかにすることが課題とし てあげられるであろう。

a. 成立過程や分布構造等にみられる御料地の実態

b. 土地取得における経緯と計画的意図の存在、又は中.心人物

c. 御料地内における空間デザイン手法

d. 御料地の解体過程と現況への影響

このうち本研究は、上記 $\mathrm{a}$ の課題に対して取り組むものである。

\section{1-3. 研究の目的・対象・方法}

本研究の目的は、明治以降東京中心部にみられた皇室御料地に関し て、その形成過程と分布を明らかにすると共に、こ扎らの土地が近代 都市の形成に対してどのような位圆付けが可能かを考察することであ る。

研究の対象は戦前の東京中心部における主な第一類御料地（後述） を中心として研究を進める。ここで言う東京中心部とは、明治以降比 較的早期に都市発展をみせた旧東京市 15 区と周辺 6 郡の一部を想定 し、およそ山手線内側及び周縁部にあたる範囲とする。研究の方法と しては、文献・資料等による調査を中心とした。まず「帝室林野局五 十年史」文能8)における記述から、昭和 12 年まで過去に存在した第一 類御料地 (陵墓地を除く) のリストアップ8) を行い、(1)御料地名、(2) 所在地、(3)編入前の主な前身、(4)編入時面積、(5)存在時期、(6)解除直 後の主な後身を明らかにした（表 1)。これらを基とし、地図資料等 により位置の特定を行い、その分布を把握した（図 3〜図 7)。従つ て、本研究での御料地の扱いは、基本的に帝室林野局による管理形態 を基調としたものとなり、また「2.御料地の概要」に閭しても「帝室 林野局五十年史」㗅的にみら扑る記述を基としたものである。

1-4. 用語について

「御料地」とは天皇及び皇室によって所有される土地を指し、「皇空 財産」として規定されるものである。「皇室財産」は御料地のほか、有 価証券等の動産も含み、明治末期以降は主にそ㧈らの運用と御料林 (御料地の一部) の経営によって皇室財源が確保されたた。た、現在 における皇居、東宮御所等は国有財産中の「皇室用財尖」であり、「皇 室財産」ではない。昭和 22 年 5 月 3 日の新憲法施行以降、「御料地」 は国内においては存在していない9)。

\section{2. 御料地の概要}

\section{2-1. 御料地の成立過程}

東京中心部における御料地は、明治維新時に既に存在していたもの ではなく、その成立をみるのは明治 18 年前後である。その母体とな るのは皇宮地であり、さらにその前身を辿扎ば明治初期における宮内 省所管官有地に求めることができる (図1)。以下にそれらの概略を述 ベ、御料地の成立過程をみていく。

i ）宮内省所管官有地

明治初年においては、東京には皇居以外に皇室用とされていた土地
は存在していない。また、皇室財産としての「御料地」は江戸期以前 にも存在していたが、そ扎らは専ら「供御の料」を出す地、つまり生 産緑地としての土地であった。江戸から明治になると、旧幕領等の土 地は政府によって上地され、こ扎らの土地は官有地として各省庁施設 用地に充てら扎。宮内省所管官有地 ${ }^{(0)}$ はその一部であったわけだ が、これらは必ずしも上地後に直接宮内省の所管となったわけではな く、他の省庁から移管さ㧈て宮内省所管となっていった土地も含んで いる"1)。皇居に続いて浜離宮、赤坂離宮等といった土地が徐々に宮内 省所管官有地となっていくが、明治初期においては基本的に「王土王 民論」といった全ての土地は天皇に帰するという考え方が存在してお

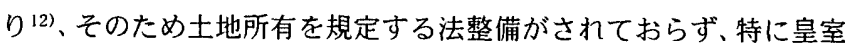
の土地を総称する呼称は存在していなかった。

ii）皇宮地

宮内省所管官有地は明治6年の「地所名称区別」(太政官布告第114 号）及び翌 7 年の「改正地所名称区別」(太政官布告第 120 号) 以降、 皇宮地とされていった。この皇宮地とは、官有地区分のうち第一種に 分類されるもので、その後「官有財産管理規則」(明治 23 年栜令 257 号）を通して大正 10 年「(旧) 国有財産法」(法律第 43 号) が制定さ れるまで官有地の下位分類として存在していた。つまり、皇宮地とは 皇室財産という意味を含有せず、あくまでも官有財産中の土地区分之 して存在した呼称であった ${ }^{13)}$ 。

iii）御料地の発生

明治 18 年の「御料局」設置前後から皇宮地の大半は御料地に編入 され、事実上皇室の財産として再度規定さ扎ていった ${ }^{14)}$ 。皇居や赤坂 離宮をはじめとする主要な土地は、この時に皇宮地から御料地に編入 されたと考えてよい。また、皇宮地以外にも民有地の買収や各省から の移管などによって編入される御料地も多数存在した。その過程は 様々であるが、特に軍用地の移管や旧武家屋敷の買収が比較的多くみ られる。これらの御料地編入は、明治 14 年頃から盛んに行わ机た「皇 室財産成立の主張」15)を受けるものであり、これらは天皇を中心と した皇室の権力を後押しするものとして莫大な皇室財産を築き、それ によって憲法の力を保つことを目的としていた。また、当時盛んにな りつつあった民権運動の影響もあり、国会開設前にこれらの財産を築 き上げておく必要があった ${ }^{16) 。 ~}$

そのような背景により、明治 18 年から 23 年の明治憲法施行までの 4,5 年間をピークとして様々な土地が御料地に編入され、皇室財産が

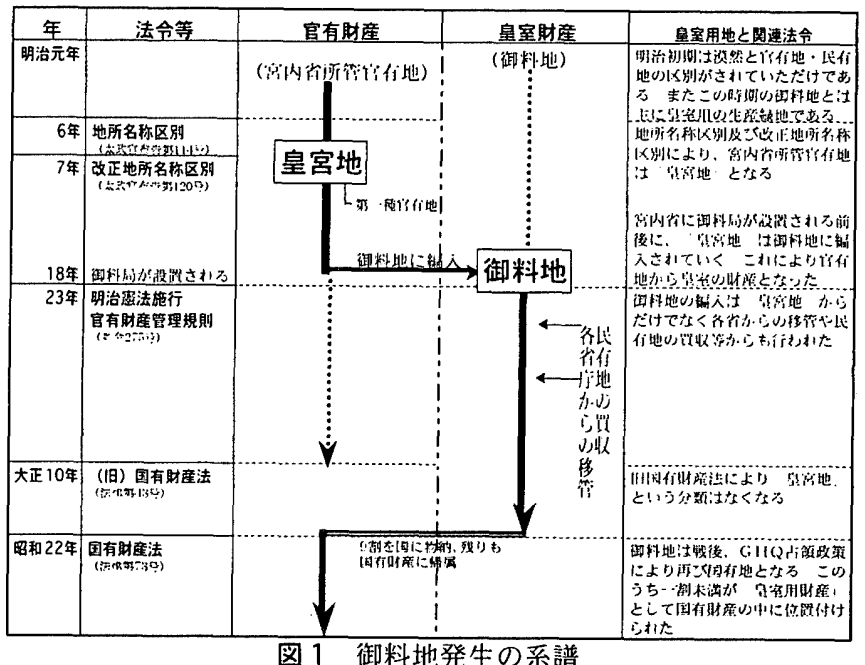

図 1 御料地発生の系譜 


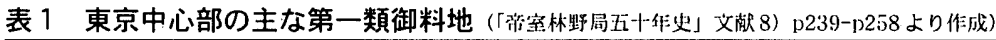

\begin{tabular}{|c|c|c|c|c|c|c|c|c|c|}
\hline No.: & (1) & 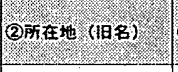 & 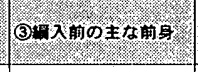 & (4) & 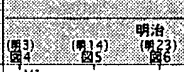 & & $\frac{1}{夭+\frac{1}{2}}$ & 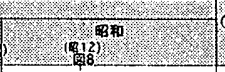 & 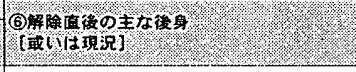 \\
\hline 1 & 要帔 & 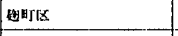 & 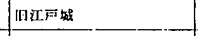 & $1,157.400 \mathrm{ui}$ & 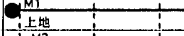 & & & 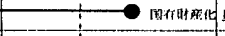 & 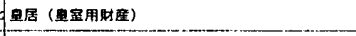 \\
\hline 2 & 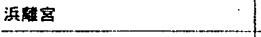 & 京枯区然地 & $\mid$ & $177.5000 \mathrm{n}$ & 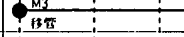 & & & 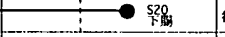 & 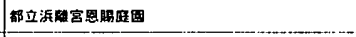 \\
\hline 3 & 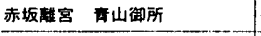 & 滦婧区 & 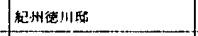 & $399.300 \mathrm{ni}$ & $M^{M-0}-$ & & & 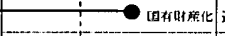 & 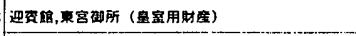 \\
\hline 4 & 伸町第二䧃料地 & 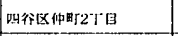 & 艮有地 & $13,900 \mathrm{ni}$ & Meo- & & & 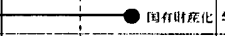 & 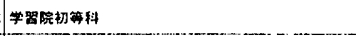 \\
\hline 5 & 水田町第一㣬料地 & 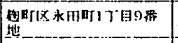 & 不响 & 7.60011 & 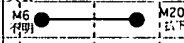 & & & & 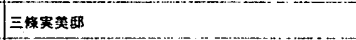 \\
\hline 6 & 南町第一㴽料地 & 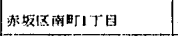 & ж目田 & $5,60001 \mathrm{n}^{\circ}$ & Ho & $\rightarrow$ & & & 中山事度的 \\
\hline 7 & 表町裸料地 & 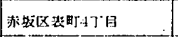 & 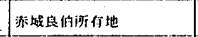 & $5.000 \mathrm{mi}$ & $h_{\text {nut }} \cdots$ & & & 119 & 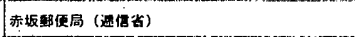 \\
\hline 8 & 芝整容 & 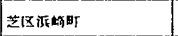 & 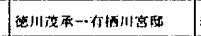 & $51.800 \mathrm{ni}$ & $\lim _{t \rightarrow \infty}$ & & & $\frac{713}{713}$ & 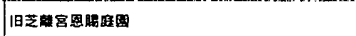 \\
\hline 9 & 福吉町御料地 & 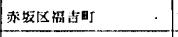 & 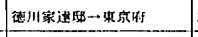 & 26..100ui & 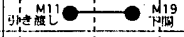 & & & & 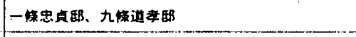 \\
\hline 10 & 水田町䅇料地 & 包町区求回町2丁目 & 罚州的一它倍地 & $4+.900 \mathrm{ni}$ & 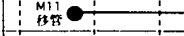 & & & 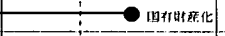 & 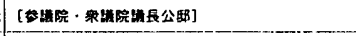 \\
\hline 11 & 南量息第一彻料地（新宿御苑) & 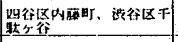 & 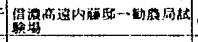 & $6.10 .000 \mathrm{ni}$ & Miz-1 & & & 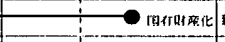 & 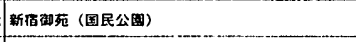 \\
\hline 12 & 粑尾井町第一御料地 & 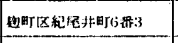 & 山绦察的 & 11.600mi & M12:- & & & 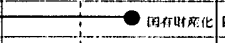 & 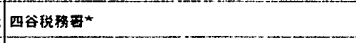 \\
\hline 13 & 伸町第一鹳料地 & 四得区伸盯丁目 & 民在地 & 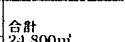 & Mis:- & & & 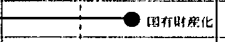 & [若莱更公圈] \\
\hline 14 & 尾張町吘料地 & 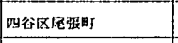 & 民在地 & $22^{24.800 n^{2}}$ & M15:- & & & 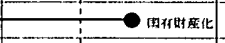 & [君慗果公圈] \\
\hline 15 & 向ヶ雕敏料地 & 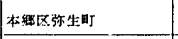 & 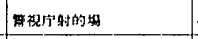 & $42.200 \mathrm{ni}$ & 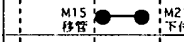 & & & & 東京共同时的会社所有地 \\
\hline 16 & 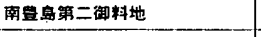 & 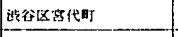 & 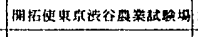 & $2 \cdot 47.00011 \mathrm{i}$ & 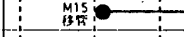 & & & 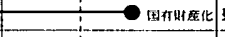 & 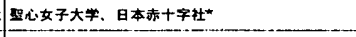 \\
\hline 17 & 南豊息第三御料地 & 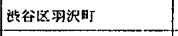 & 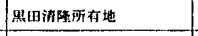 & $19.800 \mathrm{ni}$ & Mils & & & $\longrightarrow$ 望, & 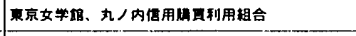 \\
\hline 18 & 南豊息第四御料地 & 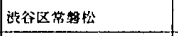 & 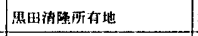 & 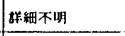 & $\begin{array}{ll}M 15 \\
\text { MII, }\end{array}$ & & & 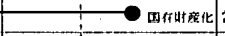 & 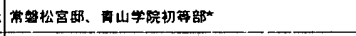 \\
\hline 19 & 南豊岛第六御叛地 & 耻行区未川山 & 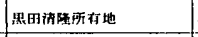 & 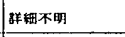 & Mls & 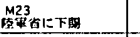 & $\frac{78}{13.2}-0$ & 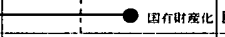 & 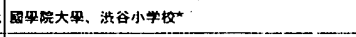 \\
\hline 20 & 上板掊解粇地 & 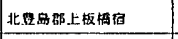 & 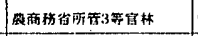 & $9.800 \mathrm{mi}$ & 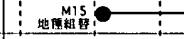 & & $\longrightarrow$ & 留 & 助需会. 化院 \\
\hline 21 & 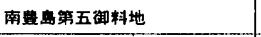 & 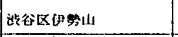 & 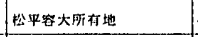 & $45,60011 \mathrm{i}$ & 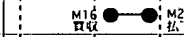 & & & & 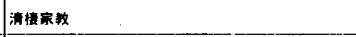 \\
\hline 22 & 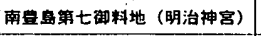 & 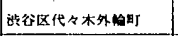 & 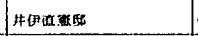 & 679.500uti & 触年- & & & 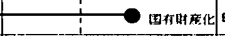 & 明治和官 \\
\hline 23 & 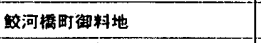 & 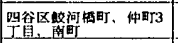 & 民存地 & $29.700 \mathrm{mi}$ & 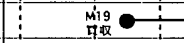 & & & $\longrightarrow$ 回相睤化 & [区立みなみもと町公圈] \\
\hline 24 & 㱏士見町第一稉料地 & 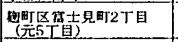 & 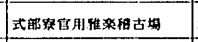 & $2.6001 \mathrm{ni}$ & 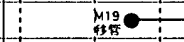 & & & $\longrightarrow$ 四相叶度化 & 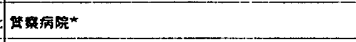 \\
\hline 25 & 䀛町第一御料地 & 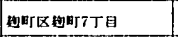 & 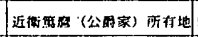 & $9.200 \mathrm{~m}$ & 率照e & & & & 本形の级同人 \\
\hline 26 & 三年町缺料地 & 姆斯区三年盯 & 工科大等用地 & Siti.50011: & $x=$ & & & $\longrightarrow$ 回相明年化 & 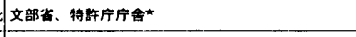 \\
\hline 27 & 溜池町䧃料地 & 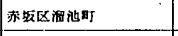 & 工科大卷用地 & $19.800 \mathrm{ni}$ & 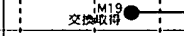 & & & 二定: & 三会显ヒル \\
\hline 28 & 上野御料地 & F得区 & $\mid$ & 97.000 in & 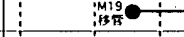 & & & - 四有相零化 & 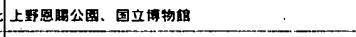 \\
\hline 29. & 愛宕町䧃料地 & 芝区带劶盯 2 T目 & 内称纷用地 & $15.90011 \mathrm{i}$ & inge- & & & 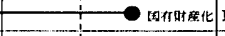 & 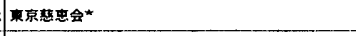 \\
\hline 30 & 永䊬町第一御料地 & 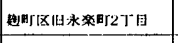 & \begin{tabular}{|l|l|} 
\\
\end{tabular} & $1.700 \mathrm{ni}$ & 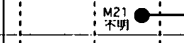 & & 省4 & & 不明 \\
\hline 31 & 木掩町第一御料地 & 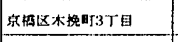 & 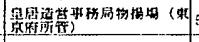 & 50011 & M21언 & & - & $F$ & 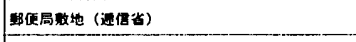 \\
\hline 32 & 三長町做料地 & 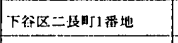 & 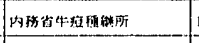 & 12880014 & M21 - M & & & & 大日本厸立济生会 \\
\hline 33 & 高裙稉料地 & 芝区的的西台时 & 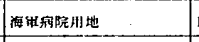 & 110.300041 & M22 & & & 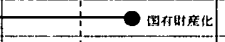 & [西松它郎、住宅话] \\
\hline 34 & 般田町解料地 & 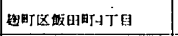 & 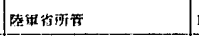 & $10.000 \mathrm{ui}$ & ${ }_{B 22}^{M}$ & M22 & & & 日本赤十字社 \\
\hline 35 & 内山下町御料地 & 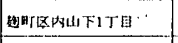 & 外枋得川地 & $13,900 \mathrm{mi}$ & 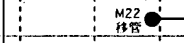 & & & 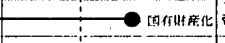 & 需国夺厂 \\
\hline 36 & 活峆町第一御料地 & 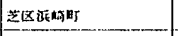 & 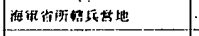 & $17.80001 i$ & S? & & & \pm 13 & 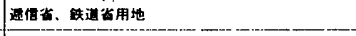 \\
\hline 37. & 慜地傲叛地 & 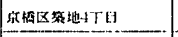 & 整果管用地 & $1+1.90001$ & 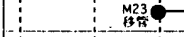 & $\longrightarrow$ 筷温: & & & 水交社 \\
\hline 38 & 雉子梅御料地 & 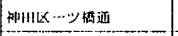 & 这因消川地 & $5.100 \mathrm{mi}$ & 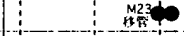 & t. & & & 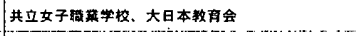 \\
\hline 39 & 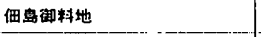 & 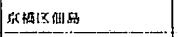 & 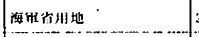 & $266.8000 \mathrm{i}$ & 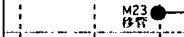 & & 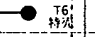 & & 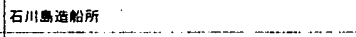 \\
\hline 40 & 一番町御料地 & 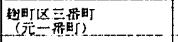 & 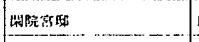 & 17.80011 & M24 & & & 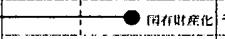 & 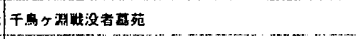 \\
\hline 41 & 原町御料地 & 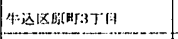 & 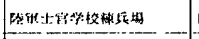 & $1+1,600011$ & M24: & 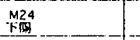 & & & 盛场粠校 \\
\hline 42 & 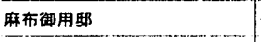 & 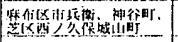 & 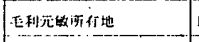 & 16i:30011: & M2 & & & Q rasillatit & 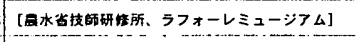 \\
\hline 43 & 菓町裸料地 & 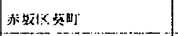 & 和明组川地 & $39.900 \ldots$ & & - & $\begin{array}{rll}T 12 \\
\text { iki.: }\end{array}$ & $\because$ & 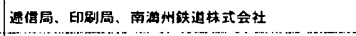 \\
\hline 44 & 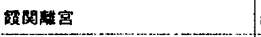 & 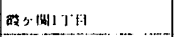 & 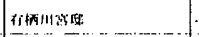 & -16.40010 & & & & - mefillexitit & 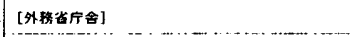 \\
\hline 45 & 高田御料地 & 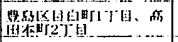 & Exite & $260.600 m$ & & $29-$ & & IArukfit: & * \\
\hline 46 & 高輸南町御料地 & 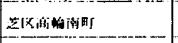 & 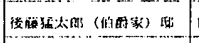 & 115.20011 & & M31 & & $\longrightarrow$ intihs & 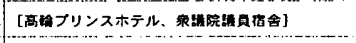 \\
\hline 47 & 内楼町梅料地 & 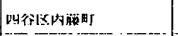 & 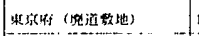 & $17014 \mathrm{i}$ & & $-M_{33}^{2}-$ & & $\longrightarrow$ 同保保: & 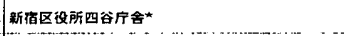 \\
\hline 48 & 孟南坂初粇地 & 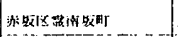 & 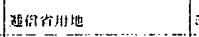 & $5, .100 \mathrm{ni}$ & & 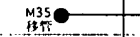 & & 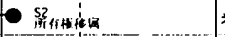 & 米国大使瞋 \\
\hline 49 & 大番町御料地 & 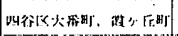 & Letit地 & $3.20011 i^{\circ}$ & & 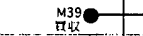 & & $\longrightarrow$ infills:ite & 不明 \\
\hline so & 田町䘖料地 & 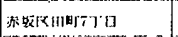 & 中.sicilifi他 & soonis & & 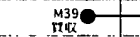 & & $\Rightarrow$ sin & 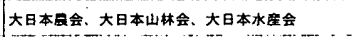 \\
\hline 51 & 䲶居坂敏料地 & 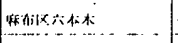 & 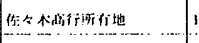 & $12.700 \mathrm{mi}$ & & Mat & 4 & $\longrightarrow$ ariturit & 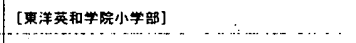 \\
\hline 52 & 有梁町御料地 & 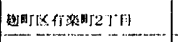 & ilitiste & 1.70011 & & 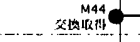 & $\rightarrow$ & 11 & 事京市 \\
\hline 53 & 鹤尾井町御料地 & 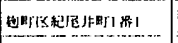 & 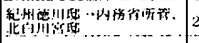 & $28.200 \mathrm{mi}$ & & & & 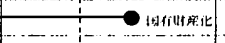 & 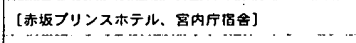 \\
\hline 54 & F山北町御料地 & 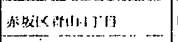 & 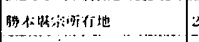 & $2: 26010+1$ & & & - & 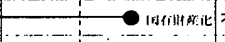 & 不明 \\
\hline 55 & 白金御料地 & 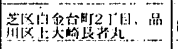 & 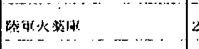 & $2=3.100111$ & & Eitang & 6 & $\longrightarrow \quad$ & 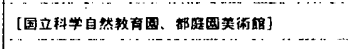 \\
\hline 56 & 東量五河岸御料地 & 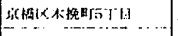 & 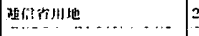 & $270 \mathrm{mi}$ & & & $\lim _{x \rightarrow 2}=0$ & T14 & 满盟局 \\
\hline 57 & 澡合御粇地 & 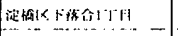 & 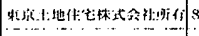 & $8.96001 \%$ & & & 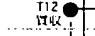 & 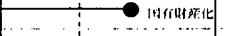 & 果芝睹クラフ] \\
\hline 58 & 三田台町鲜料地 & 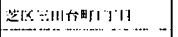 & 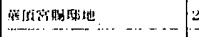 & $20.80001 \mathrm{i}$ & & & T34: & $\longrightarrow$ infiurferte & 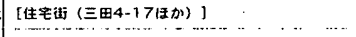 \\
\hline 59 & 盛同町袢料地 & 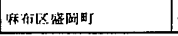 & 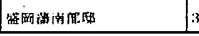 & 32.000111 & & & & $\longrightarrow$ infiutratit & 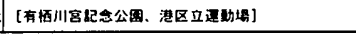 \\
\hline
\end{tabular}

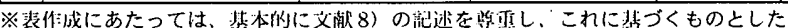

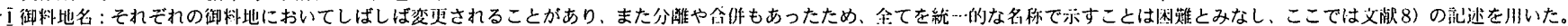

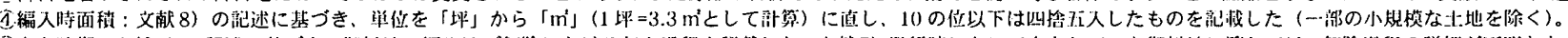

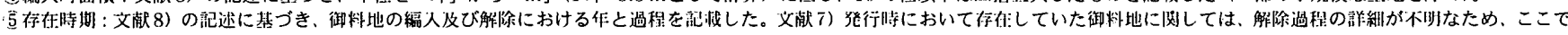

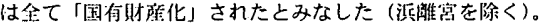

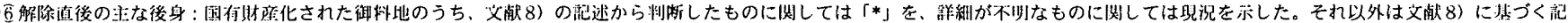
述によるもの、或いは文献等によりリ颃かになっているものである。 
成立した。

\section{2-2. 御料地の愳額と土地用途分額}

帝室林野局によって、御料地は(1)宮殿や御苑等皇室沐直接使用する 「第一類御料地」と、(2)不材を中心とした諸物資を生座する収益事業 用の「第二類御料地」にまず大別された。さらにそれでれは、明治憲 法の皇室典範第8 章における「世伝御料の制」により「世伝御料」と 「普通御料」とに分けら孙る。世伝御料とは、編入されることによっ て「分割譲渡することのできない処分し得ない土地」となる御料地で ある。また、土地用途 (地目) としては宮殿地・陵墓地・林地・農地・

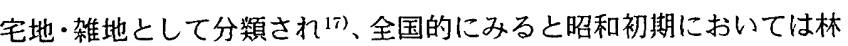
地が $97 \%$ 、農地が3\%でその他は合計して0.5\%未満上なっており ${ }^{18}$ (図2参照)、北海道、不曾方面を中心とした御料林が非常に大きい割 合を占めていたことが分かる。昭和 12 年の時点で全国の御料地面積 は約 140 万 ha（うち第一類が約 1,758ha）であり、そのうち東京府 は第一類が約 $583 \mathrm{ha、}$ 第二類が約 1,765 ha となっている ${ }^{19) 。 し か し 、 ~}$ 東京中心部に関しては東京府内の大部分の第一類御料地が集中し、逆 に第二類御料地は殆ど存在せず、東京府内においてはそれらの偏りが はっきりしていた。
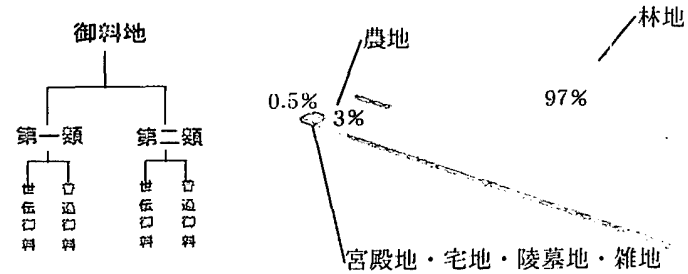

图 2 御料地の種類と土地用途別にみた面穦比率（昭和初期）

\section{2-3. 陵基地と下賜地}

陵墓地は、前述したような御料地の成立過程とは異なる過程を有 し、また帝室林野局の管理下にも置かれておらず、その他の御料地と は性格の異なる御料地であった。一方、下賜地は、御料地から解除さ れた土地の中でも、御料地或いは天皇・皇室との結びつきがその後も 保たれた例外的な存在であった。以下に、これらの概要を述べる。

\section{i ) 陵墓地}

陵墓とは主に天皇のほか皇室の墓を指し、その他各皇族の墓等も含 む。陵墓地は主として第一類御料地に属した。陵墓地注明治初期にお いては内務省の所管であったが、明治 11 年の太政官達第 6 号により 宮内省所管となり ${ }^{20)}$ 、「改正地所名称区別」「官有財産管理規則」下 においては皇宮地と共に第一種官有地の「神地」として分類されてい る。陵墓地は、この「神地」を前身として御料地に編入された。陵墓 地は全国的にみると京都を中心として全国に分布し、その数は昭和 12 年の時点で 391 箇所（参考地が 51 箇所）にものぼる21!。東京都区 部においては小石川区の豊島岡皇族墓地をはじめ、芝区二本榎の興意 親王墓、下谷区上野公園地内の輪王寺宮墓があげら扒、東京府下にお いてはこ扎に南多摩郡浅川町他の多摩御陵が加わる22)。

\section{ii）土地の下賜および下付地}

東京中心部においては、御料地編入と同時期に明治 19年〜23年を ピーク ${ }^{23)}$ として個人、企業、東京市等に対して土地の下賜が行われ ている。土地の下賜は、個人や企業（いずれも華族に関するものが主） の業續等を笑励して行われるケースや、長期間継続してその土地を借 用していた場合に行われるケースなど様々であり、地方公共団体に対
しての下賜はおよそ皇室内の記念的意味合いを含んだ場合が多い(恩 賜公園等)。また、下賜に準ずる土地の「下付」も各所で行わ扎てい る。これらはその土地が御料地から解除される過程2.1) の一つと言え るが、その他にも「払い下げ」や「無償譲渡」など御料地の解除の過 程はそれぞ扎明確に区別さ㧈ていた。

iii）皇族賜邸地

明治以降、各皇族部用地は基本的に政府によって用意された。その うち、天皇からの下賜地として御料地の中から与えられた宅地は皇族 賜邸地と呼ばれた 2iう。しかし一般の下賜地と違う点は、まず皇族がこ れらの賜邸地を「返上」するケースがあり、その際にはその土地は再 び御料地に編入さ㧈ていたこと ${ }^{26)}$ 、また賜邸地自体の管理も帝室林野 局（御料局を母体とする）にあったこと、さらには官有財産としては 第二種官有地に分頙されていたことがあり、およそ御料地に準ずる土 地となっていたとみることができる。

尚、賜邸地は皇族すべてに与えられていたわけではなく、賜祁地を 持たない皇族も存在し、その場合は御料地を「拝借」するなどして邸 宅を構えていた ${ }^{2 i) 。 ~}$

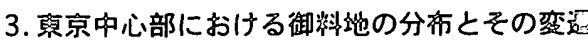

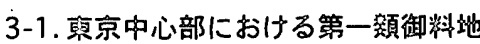

皇居を中心として、東京中心部には第一類御料地が最も多く集楥し た。ここでは、表 1 のリストに基づき、明治 3 年から昭和 12 年まで における5つの時期28)について、こ扎らの分布図を作成した ${ }^{29)}$ 。尚、 明治 3 年・14 年の図に関しては、皇宮地又はその前身である宮内省 所管官有地の分布となる。また、昭和 12 年における皇族賜邸地およ び昭和 12 年までに下賜、下付さ㧈た土地の分布図も作成した (図8)。

\section{3-2. 明治憲法施行までの分市の变遠}

i) 明治 3 年 (図 3)

前述した通り、明治初年には皇城30)のみが皇室用の土地であった。 明治 3 年は皇城以外に浜離宮が初めて宮内省所管となった時期であ る。この時、赤坂離宮と新宿御苑の土地は上地されておらず、それぞ れ紀州德川邸と信濃高遠内藤邸となっていた。また、既に上地されて いた土地も、他の各官庁施設用地、もしくは桑茶畑として使用さ㧈て いた時期である。

ii）明治 14 年（図 4)

この頃には、明治 7 年「改正地所名称区別」等の土地制度を規定す る法整備によって、皇宮地といった皇室用の土地としての枠が設けら れ、明治初期においてみられた王土的思想はもはや現実味を帯びなく なっていた。

明治5年には紀州徳川茂承より赤坂離宮となる広大な土地が上地さ 化宮内省の所管となり、同時に赤坂離宮の周囲には火除け、衛生等を 目的とした附属地が設けられた。赤坂離宮は明治 6 年 5 月に皇城が炎 上したため明治 21 年まで仮皇居とされたが、この一件によって赤坂 離宮は内部の整備のみならず、青山御所の敷地を追加編入するなど領 域をさらに桩大していき、皇室にとっての重要性を確立していくきっ かけとなったと見ることができる。さらに、皇城が炎上したことに よって皇居造営の必要性が高まったことをみれで、皇居という広大な 土地が再整備されるだけでなく、その整備自体が東京中心部の再整備 そのものにもなり、東京の首都としての認識を広める大きな要因と なったと捉えることができる。その他、「女官下り邸地」として確保 
された「5. 永田町第一御料地」、「8. 芝離宮」、「11. 植物御苑」（後の 新宿御苑）といった主要御料地が増えているのに加えて、「9.福吉町 御料地」、110.永田町（第二）御料地」といつた主に邸宅地として機 能した御料地の発生も見られる。

明治 14 年前後は、前述した「皇室財産成立の主張」が盛んに行わ 㧈る時期で、皇宮地にはこ㧈らの主張によっておよそ皇室の所有地と しての認識が広まっていったと思わ扎る。しかし、この時点ではこれ らの土地はまだ御料地には編入されておらず、皇室財産として規定さ れ得るものではなかった。

iii）明治 23 年（図 5)

明治 18 年前後、皇宮地となっていた土地の大部分は御料地に編入 され、皇室財産として規定された。明治 17 年〜 20 年は俗に「鹿鳴 館時代」と呼ばれ ${ }^{311}$ 、政府が中心となって様々な面における「西欧 化」が進められた時期であった。特に都市・建築面での「西欧化」は 顕著であり、英国人建築家コンドルをはじめとしてエンデ、ベックマ ン、ホープレヒトといったドイツ人建築家らによる一連の「官庁集中
計画」はそのことを如実に表していると言える。御料地はこのような 時代背景の中でその大量な土地編入をみたのである。

明治 23 年の分布図においては、新たに代々木御料地（明治 20 年 に南豊島第七御料地に改称、後に明治神宮となる)や渋谷第一〜第五 御料地（明治 20 年に南豊島第二〜第六御料地に改称）といった大規 模御料地が発生していると同時に、赤坂離宮の接続附属御料地も増加 しているのが確認できる。また、皇居造営及びその前庭である宮城外 苑の整備も明治 17 年から始まっており、そ机に伴う用地も大量に取 得された。東京中心部での主要な御料地は、明治憲法施行の明治 23 年までにほぼ編入されており、ここでその基盤が整ったと言える。

明治初期からの変遷を振り返ってみると、皇居を中心として西方面 と南方向にその分布が広がっていったことが認められる。西方面には 大規模な御料地が隣り合って増加をみせたのに対し、南方面には幾つ かの御料地が集中する地区が分散して発生することによってその分布 の拡大をみせた。この要因の一つには、江戸期以降に行わ抗た武家地 開発との密接な関倸性があげられ、御料地のベースとなっていた旧幕

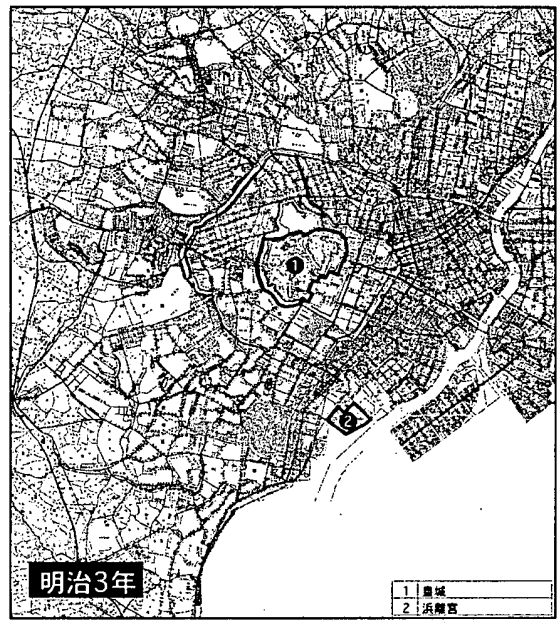

図 3 明治 3 年における分布

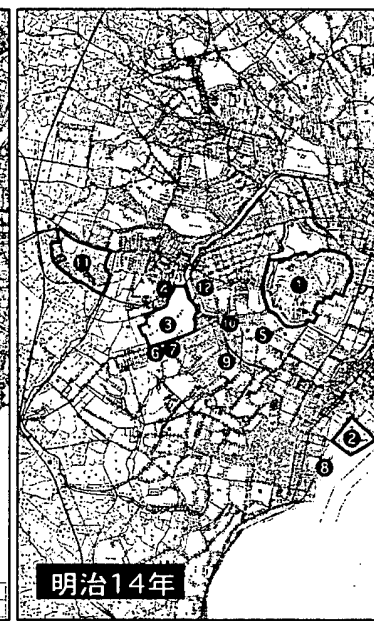

図 4 明治 14 年における分布

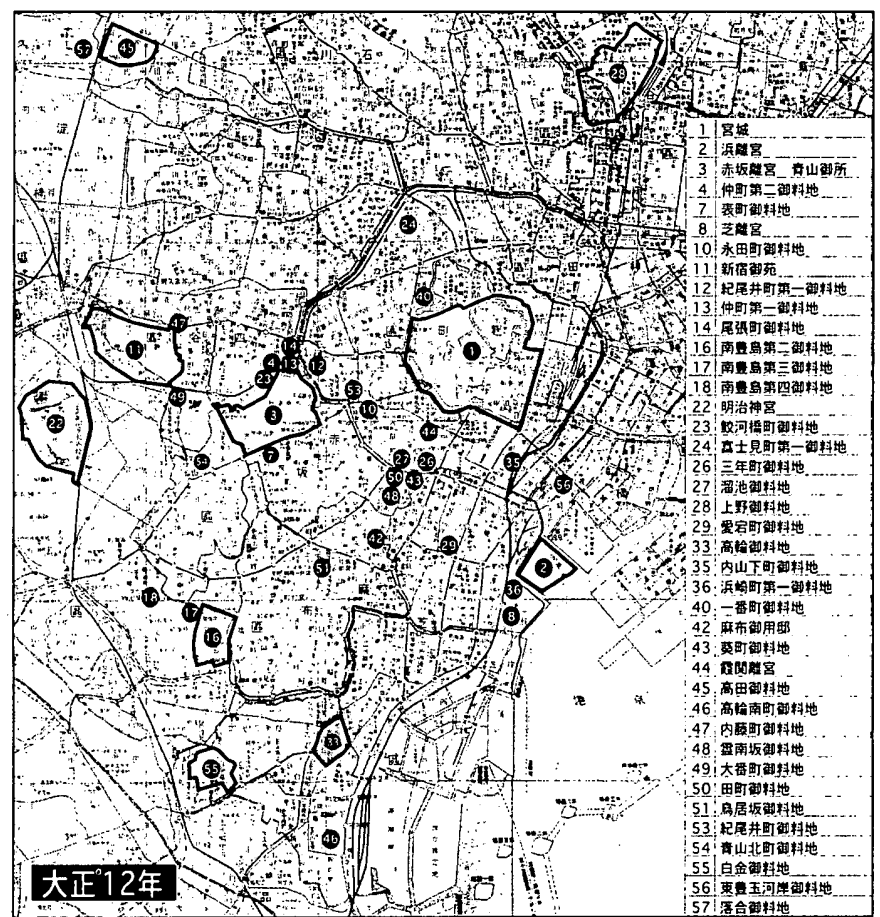

图 6 大正 12 年における分布

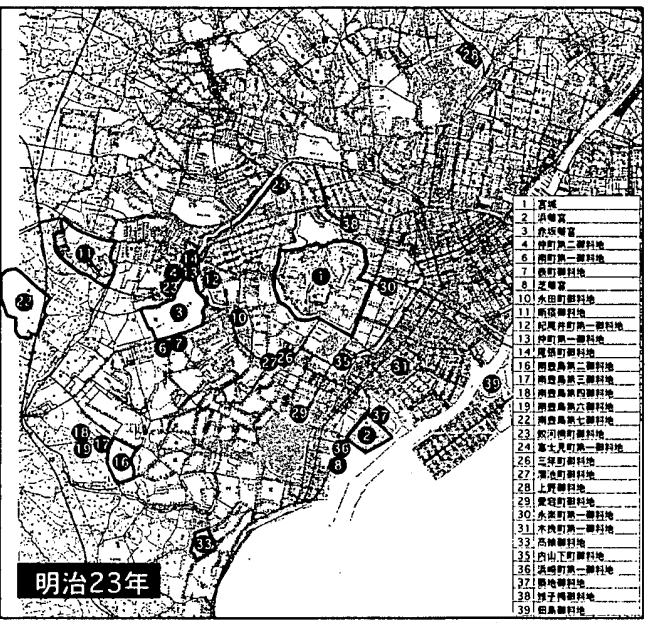

図 5 明治 23 年における分布

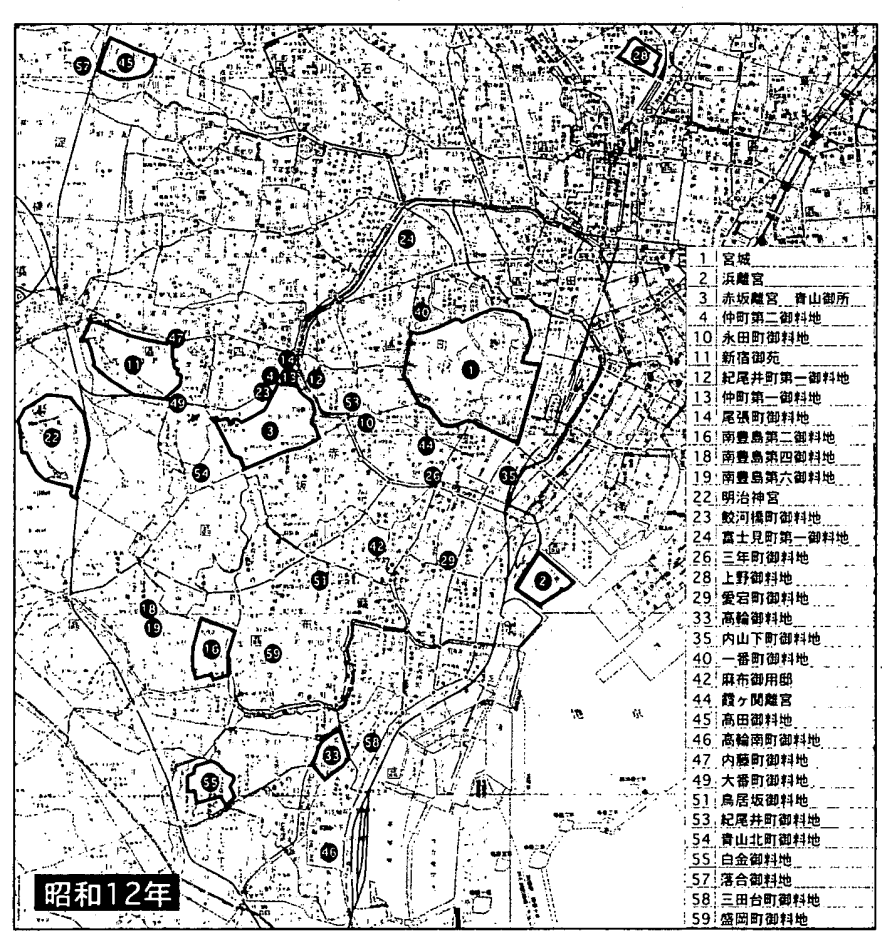

図 7 昭和 12 年における分布

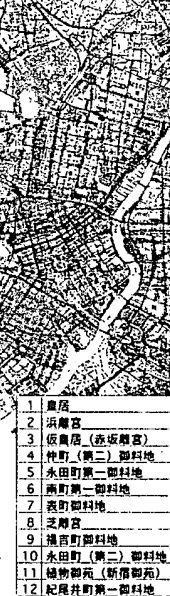

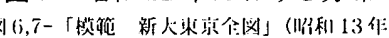


僚等の武家屋敷が、高台の立地条件の良い場所であるこれら西方面 （四谷・粪町台地）と南方面（赤坂・麻布台地、芝・白金台地）を中 心として構えられていたことが大きく影響している。また、御料地の 分布の広がり方に差異が生じたことに関しては、前者は緩やかな面的 広がりを持つ台地であり、比較的まとまった土地が武家屋敷として確 保さ机ていたのに対し、後者の山の手地区には、舌状の突起台地や島 状の独立した台地が数多く存在し、その地勢に従って武家地開発が進

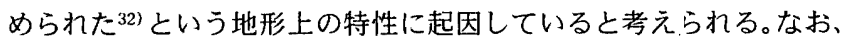
後の神宮外苑となる青山練兵場も御料地編入のピークと同時期に民有 地買収によって用地取得が行わ㧈ていること ${ }^{33)}$ を付記しておく。

\section{3-3. 明治憲法施行以降の分布の变遷}

明治 23 年以降においては御料地の分布は多少の変化が見られるだ けで、大正、昭和期になると編入される御料地は非常に少なくなる。 しかし大正以降は神宮内苑外苑、恩賜公園等のモニュメント的な空間 への転換や、風致地区・美観地区を始めとする法整備等によって、御 料地のそれぞれの特質が強調されていった時期である。

i ) 大正 12 年（図6）

明治憲法施行までの分布においては、宮城の西、南方向に広がりを 見せていったが、明治後期になると宮城の北方向に高时御料地（学習 院敷地）や上野御料地の公園敷地 ${ }^{3-1)}$ といった大規模な御料地が発生 している。しかし、これらは他の御料地と関連性をもって取得されて いったというよりは寧ろ、宮城を中心とした御料地の集積する地域と は幾分孤立した位置に取得され、以前の御料地分布の広がり方とは性 格を異にするものであると捉えら扎る。しかし一方では、従来の東 西・南北の両軸上にも御料地の増加は見られ、「44. 霞関離宮」、「48. 霊南坂御料地小「42. 麻布御殿」、「46. 高輪南町御料地」といつた中 規模の宅地系御料地が、華族や有産階級等の屋敷が集中する山の手方 面に集中して発生しているのが認められる。

大正 12 年 9 月の関東大震災においては、都心部においてオープン スペースとなっていた御料地が避難所として機能し、芝離宮等には仮

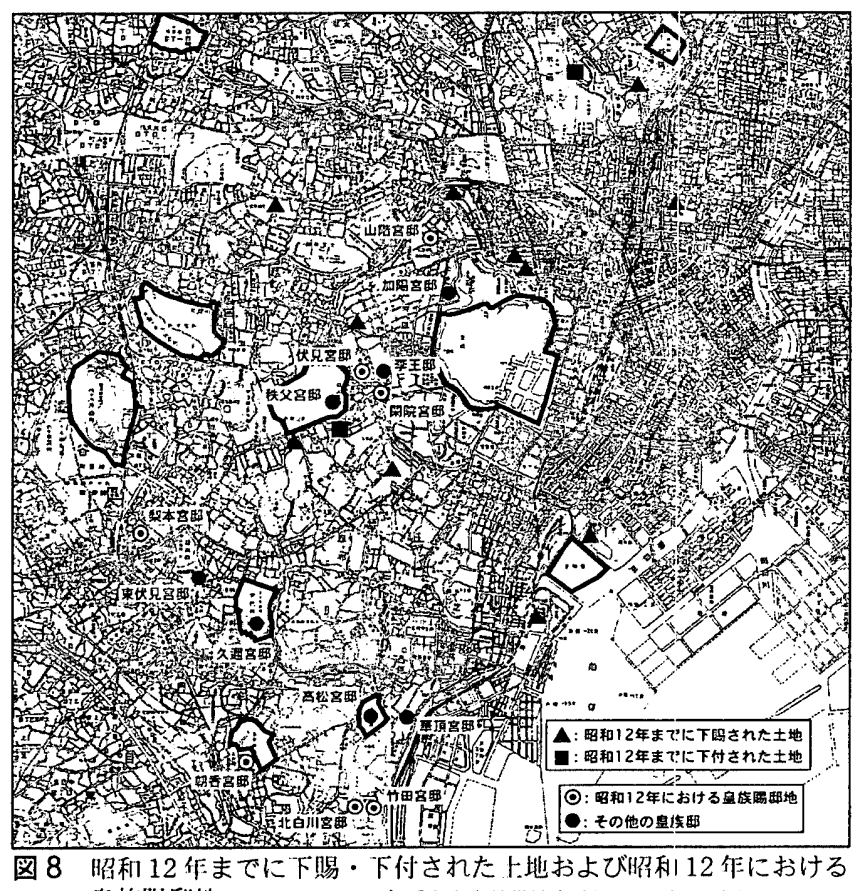

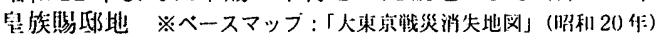

設バラックの建設も行われた ${ }^{35)}$ 。また、大正 9 年には明治神宮の鎮 座祭が行わ扎、昭和 2 年には神宮外苑が一般に公開されており、東京 の中心部に巨大な皇室モニュメントが誕生した。

大正 12 年の分布は、本稿で示した 5 期の分布のうち最も御料地数 が多い。しかし、この後大正 13 年 1 月には「皇太子 (昭和天皇) 御 成婚記念」として上野御料地の公園部、芝離宮、猿江御料地（第二類 御料地/対象外）が東京市に下賜され、それぞれ恩賜公園として開放 されていく。これは震災直後、これらの御料地が避難所として機能し たことが大きく影響し、都市部へのそのようなオープンスペースの必 要性が高まったことが直接の要因であると考えら机る。こ扎らの御料 地開放の背景には当然大正デモクラシーによる民主主義的改革運動の 隆盛が根底にあるが、これら3御料地の一斉開放は、政治指導者をは じめ社会全体として御料地に対する考えの変化を具体的に表すもので あったと捉えることができる。

\section{ii) 昭和 12 年 (図 7)}

この分布においては、大正 12 年と比べても全体的な分布構造の変 化は基本的にはみられず、宮城、赤坂離宮、新宿御苑、明治神宮に神 宮外苑を加えた東西方向の軸と、宮城から高輪御料地、白金御料地、 南豊島第二御料地方面にのびる山の手屋敷街の南北方向の軸の、両軸 による分布構造を基本的に崩していない。皇族は賜邱地を御料地の中 から与えら扒、又は御料地を「拝借」して邸宅を構えていたことから も、皇族邸は宮殿や御苑と共にこの両軸に集中し、皇室関連用地が固 まって存在する地域が形成されたと言える。それに対し、この軸から はずれている土地が下賜地あるいは下付地となり、一般に開放されて いったとみることができるであろう（図 8)。

\section{4. 考察}

以上を踏まえ、御料地の成立時における政治動向及び社会背景との 関連性と、大正〜昭和戦前期における都市計画制度との関連性に着目 して、東京の都市形成過程における御料地の位置付けの考察を行う。

\section{4-1.「西欧化」としての御料地の成立}

明治 10 年代に見られた「皇室財産成立の主張」は、明らかに西欧 列強諸国における王室制度の影響を受けているものであり、御料財産 を築くことは内発的な政策というよりはむしろ、西欧諸国の制度を模 倣した結果によるものであったと言える。つまり、皇室財産の成立は 常に西欧諸国の王室制度が念頭にあり、特にそ㧈らと日本の皇室との 比較をし、西欧諸国に劣ることのない皇室財産を筑くことが重要視さ れていたということである。事実、当時数多く見ら扎た皇室財産成立 の主張の中でも、西欧の君主国を例にあげて日本の皇室と比較してい るものは多い。例えば中村弥六による「帝室御有/財産ヨ今日二制定 ス可キノ意見書」(文献18）所収）においては「各立君国費及ビ帝室 費比較表」を提示して各国の王室財産が「帝王ノ尊厳ヨ保チ一国习主 宰上欠ク可カラザル」存在であることを指摘しており、福沢諭吉の 「帝室論ノ一節」(文献 18）所収）においても西欧諸国の王室費の実 状をあげて比較し、「帝室費ノ豊ナラン」ことを主張している。この ようなことからも、皇室財産の成立とは当時不平等条約を撤廃するこ とを目的とした欧化主義時代の流狆の中に位置付けることができ、 従って御料地の成立もこの「鹿鳴館時代」において様々にみられた 「西欧化」の一つとしてみることができる36)。東京に西欧諸国都市を 模倣した王候貴族領により構成される首都を建設しようとしたとする 
と、「鹿鳴館時代」において東京を「西欧化」しようとしたものは、 コンドルらのバロック都市計画といった建築様式的なものに止まら ず、このように都市基盤としての土地占有形態をも模做することで成 し遂げようとするものであったと捉えることができるであろう。

\section{4-2. 風致地区・美観地区との関係}

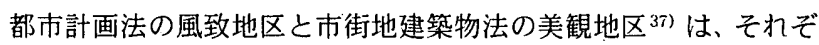
れ大正8年に姉妹法として公布されたが、両制度の地区指定は御料地 或いは御料地に係わる地域と非常に密接な関係を持っていた。表2の 通り御料地に倸わる風致地区指定は全国で 18 箇所以上にものぼり、 美観地区指定に関しても数少ない指定の中で御料地に係わる地域が指

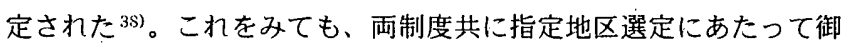
料地が中心的に考えら扎てたことは間違いない。

風致地区・美観地区といった都市計画上の制度と御料地との密接な 関係性が存在していた要因としては、一つには多くの研究者 ${ }^{39)}$ が指 摘しているように「天皇制の維持・強化」という政治的意図を含んで いたということがあげられる。しかし、一方では都市美を維持する側 として、これら御料地が有していた様々な特権を積極的に活用するこ とによって、都市景観問題に対処しようとしたという見方も考えられ るはずである。その特権とは、まずこれらの御料地には皇室財政を バックアップとした膨大な資金投資や当時の最高技術が結集されたこ と40)である。さらには対象地区の選定や事業の展開など様々な過程 において、御料地を中心に据えることによって人々の賛同と理解が得 られ易かったということも考えられるであろう。風致地区・美観地区 と御料地との関係性は、このように御料地の持つ様々な特権に頼るこ とによって、実験的に両制度を遂行しようとするものであったという 解䣋が可能である。

表 2 皇室御料地に倸わる風致地区指定

\begin{tabular}{|c|c|c|c|c|c|}
\hline 御料地名 & 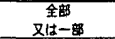 & 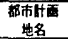 & 風致地区名 & 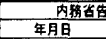 & 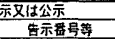 \\
\hline 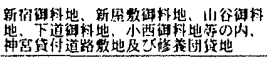 & 金部 & 䔩京 & 朋治神宫 & 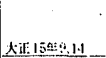 & 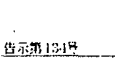 \\
\hline 堅多見 & 金部 & 䔩索 & 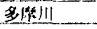 & 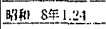 & 㸃和 190 \\
\hline 느ㄴㅗㅛ & 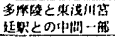 & AEt & 渃川 & 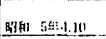 & 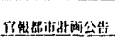 \\
\hline 京能皇宫 & 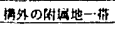 & 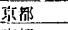 & & 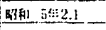 & 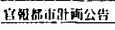 \\
\hline 二条雄宮 & 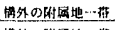 & 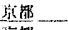 & & siafla & 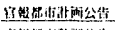 \\
\hline 青離宫 & 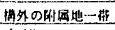 & 策敬 & & Silat is & 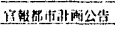 \\
\hline 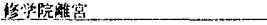 & 金讳 & 炽㓠 & & 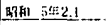 & 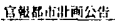 \\
\hline 近楮 (水说地) & 全部 & 京策 & & gitan is & 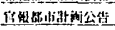 \\
\hline 象们 (碐垔地) & 全整 & 等檚 & & Bifital if 2.1 & 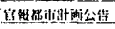 \\
\hline 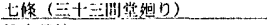 & 金器 & 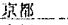 & & Iytal Sff: 2.1 & 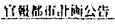 \\
\hline 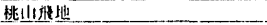 & 金部 & it & $\ldots$ & (4) & 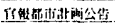 \\
\hline 笠. & 金觔 & 3 征 & & 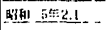 & 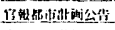 \\
\hline 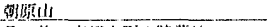 & 全的 & 勧策 & $-\ldots$ & 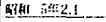 & 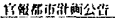 \\
\hline 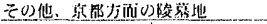 & 企故 & Kon & & 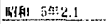 & If \\
\hline 血蕉山 & 企慗 & 坚星 & 余萑背 & 떠네 $92=12.15$ & 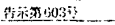 \\
\hline 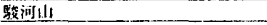 & 唡 & 政琹 & Q1.10111 & $141+1199: 12.15$ & 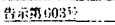 \\
\hline 小粸代 & 金部 & 三艋 & 洲诘 & 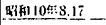 & 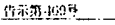 \\
\hline 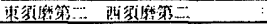 & 金初 & 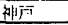 & Fillis & Q & 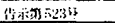 \\
\hline
\end{tabular}

\section{5. 結語}

以上の調查・分析により、東京中心部における皇室御料地に関して 判明したことは次の通りである。

(1)御料地は維新後、明治政府によって上地さ扎た旧幕領等の土地、す なわち官有地をべースとして成立した。その発生をみるのは明治 18 年前後で、「宮内省所管官有地 $\rightarrow$ 皇宮地 $\rightarrow$ 御料地」という過程を経て 成立した。その後は各省庁からの移管や民有地の買収によって明治 23 年までに大量の土地が御料地として確保された。また、御料地は 全国的にみると、御料林を中心とした第二類御料地が圧倒的に大部分 を占めていたが、東京中心部においては宮殿・離宮等の第一類御料地 が集中して存在していた。

(2)東京中心部における御料地 (或いは前身となる皇宮地)の分布変遷
は、皇居を中心として、まず大規模な隣り合う土地が西に向かって確 保され、やや遅れて南方向に分散してその分布拡大をみせ、明治 23 年の明治憲法施行までにほぼその分布構造の基盤を整えた。以降は大 きな分布構造の変化はみら扎ず、宮城、赤坂離宮、新宿御苑、明治神 宮に神宮外苑を加えた東西方向の軸と、宮城から高輪御料地、白金御 料地、南豊島第二御料地方面に延びる山の手屋敷街の南北方向の軸 の、両軸による分布構造が保た扒た。

(3)東京の都市形成過程の中で、明治 10 年代後半の御料地の成立は、 都市の「西欧化」の一つとして欧化主義時代の流れの中に位置づける ことが可能である。また、風致地区・美観地区の地区選定にあたって 御料地が中心に据えられていた理由としては、御料地が有していた 様々な特権を積極的に利用することで、両制度をスムーズに遂行し、 都市景観問題に対処しようとしたという見方が可能である。

本稿に拀いては、東京中心部における皇室御料地の成立過程や分布 構造に関して最も基礎的な情報を収集・整理した。今後はこれらを基 に、御料地の展開における計画意図等を明らかにすることが課題とな るが、そのためには国内全土における御料地や、さらには植民地にお ける御料地の存在も把握しておく必要がある。また、冒頭にあげたそ の他の研究課題に関しても非常に重要な問題を内包しており、これに 関しては稿を改めて述べることとしたい。

\section{謝辞・付記}

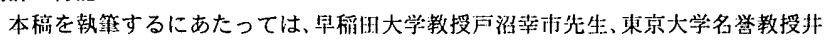
非久登先生に大変お世活になりました。この場を借りて、感謝の意を表したいと思い ます。本䅭は早稻田大学大学院に提出した 1999 年度修士論文「東京中心部における

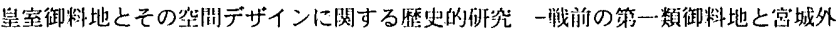
苑を中心としてー」の一蔀を加筷、修正したもので、同㥞の趣旨の発表を1999年度 日本建筑学会関束支部砋究発表会にて行いました。

\section{注記}

1）文献 1) p26

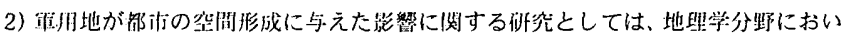
て文献2）があげられるが、その中で松以は「同様の佃究例はほとんど見いだすこと ができない」としている。また、泉空関係の土地については、緦济論の視点からこれ

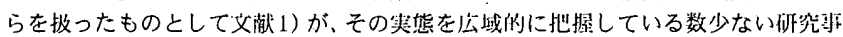
例としてあげられる。

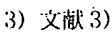

4) 文㴾-1)

5) 文献 5)

6) 文献 6)

7) 文湖 7 )

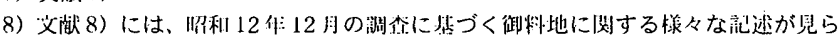

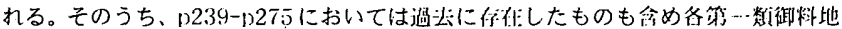

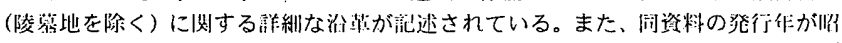

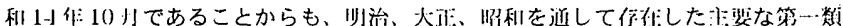

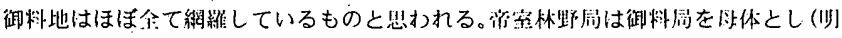

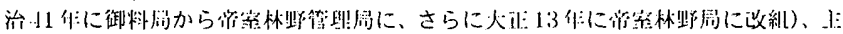

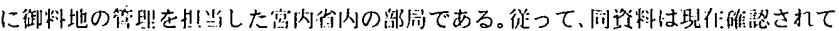

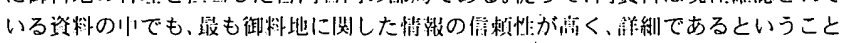

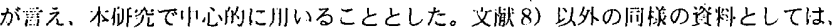

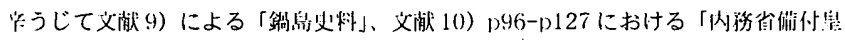

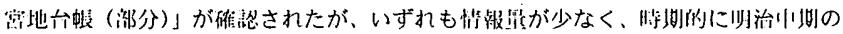

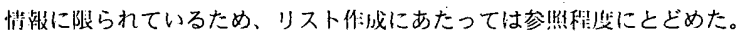

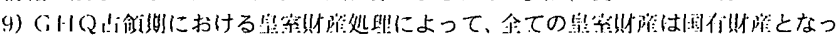

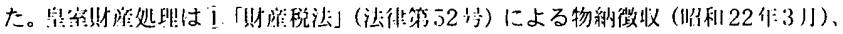

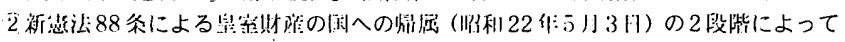
行むれた。

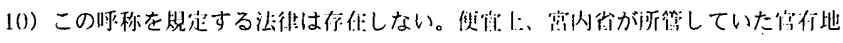
としてこの多称を川いる。

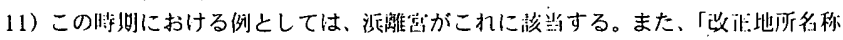

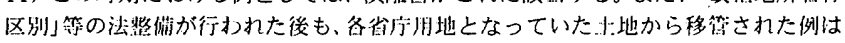
非常に多い (洨 1 参照)。

12）文献 11) p6

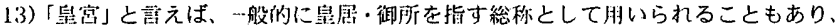

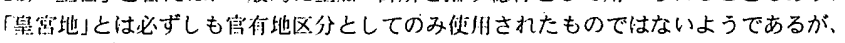




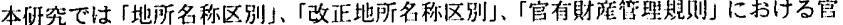
有地区分として統一ーし、この呼称を扱う。

14）この際、官有財碚としては皇容地であり続け、同じく買収等によって編人さ机 た御料地も鼠宣地に編入されていたと思われる。また、「改正地河名称区别」から「官

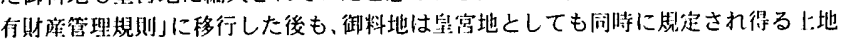

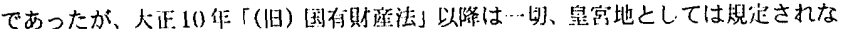

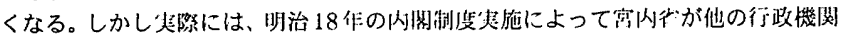

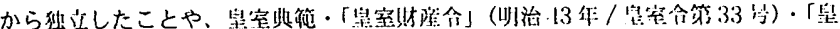

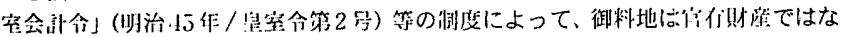

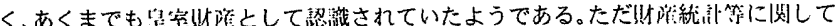

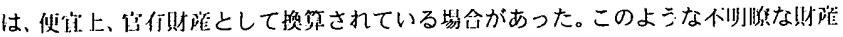

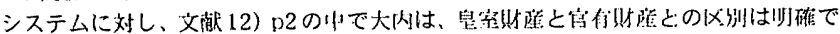

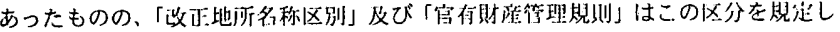

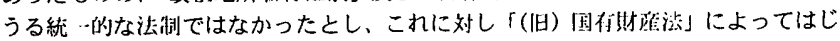

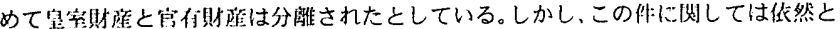
して不明な点が多く、さらなる梌即を装すものと思打れる。

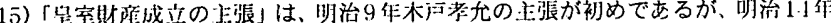

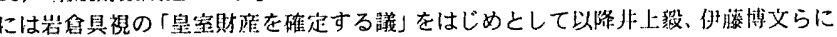
よって椂々な上張がなされた。また、民間からとしては福沢諭吉や小朴尔六（林学愽 上）の志張等が見ら扎る。文献1）p21-p26

16）文献 1) $\mathrm{p} 21-\mathrm{p} 27$

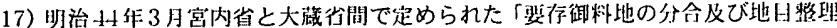
方針」による。文献 8）p392

18）文㗅 1）p111

19）文献8）p 232-235 なお東京府においては、このう第一類は約70\%が世伝御 料地、第二類は世伝御料地はなく全て普通御料地となっている。

20) 文献 8) $\mathrm{p} 275$

21) 弣上

22）文献13）p12-27によれば、天皇陵はその天皇と生前に関係が浑かった地点2つ

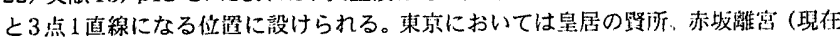

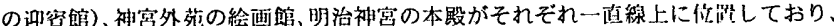

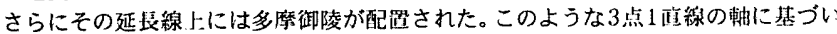

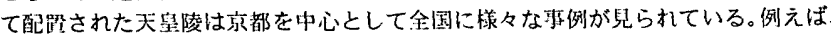

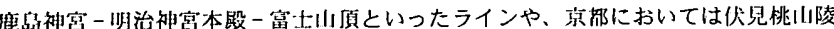

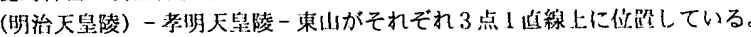

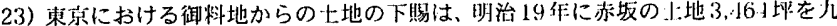
條道考に下晿されたのが初めである。文献 8) p930-931

2.1) 上地の下晹および下付は普通御料だけでなく世伝御料からも行われたが、その 際には該当の土地を一度世伝御料から普通御料に灾した上で行わ机ている。また、明

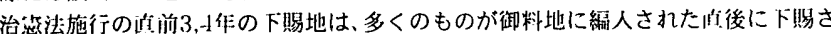

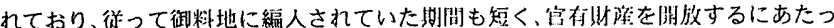

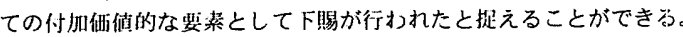

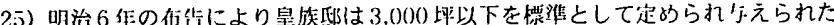

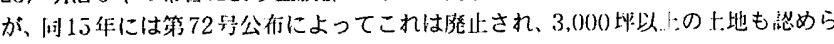
れた。文朝 1.J) p31.1-p317

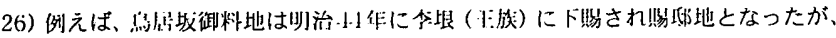

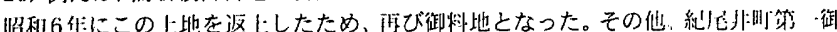

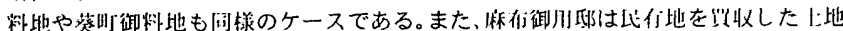

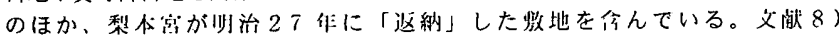
1) $252,02.16,122.18 ., 122.1 .1$

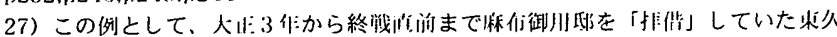

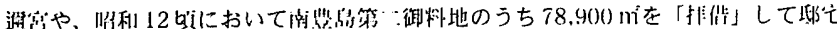

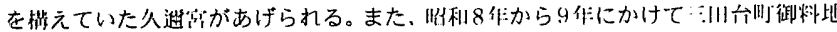

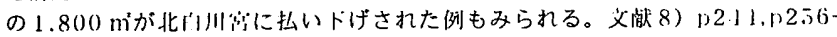
$\mathrm{p} 25 \overline{5}, \mathrm{p} 253$

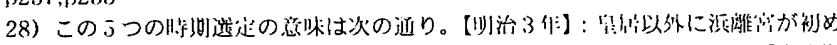

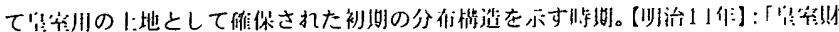

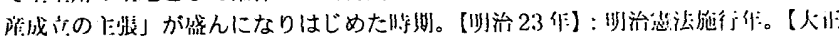

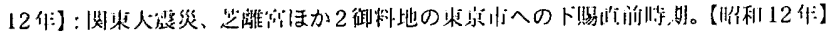

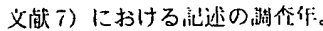

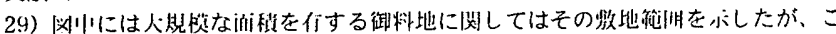

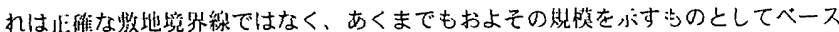
マッフに甚づいて俳成した䇚㳉である。

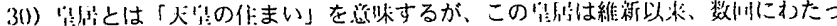

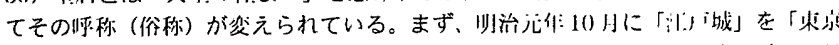

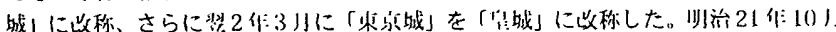

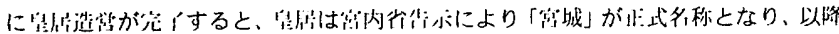

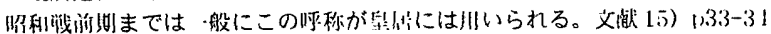

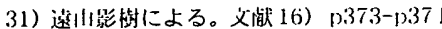

32) 文献-4) $025-p 27$

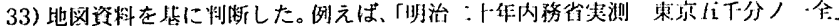

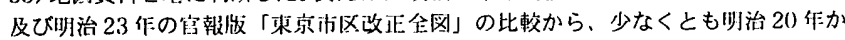
ら 23 年の間に朋地跬收が行才れたと考えられる。

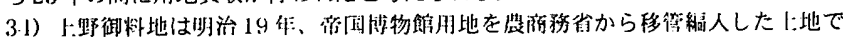

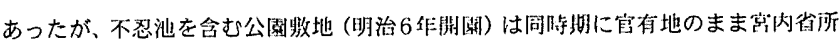
管となっただけで、御料地とはされていなかった。そ执が御料地（皇宫地附假地）と して編入されるのは明治 36 年 9 月である。文献 8） p25.1-p255, 作表 $\mathrm{p} 21$ 35) 文䧻 17) p117(0)-p1172

36）例えば、当時日标が「西欧化」に扰いてモデルとしていたイギリスに符日する

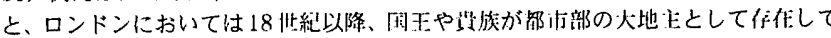

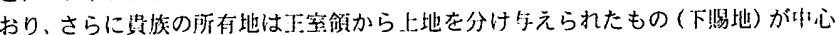

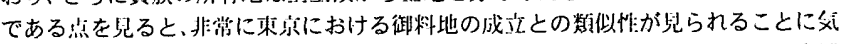

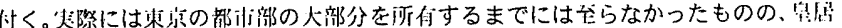

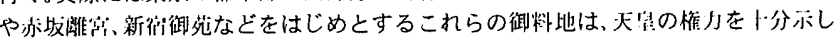

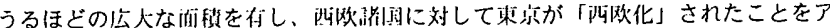
ヒールするのに非常に付効なッ硎を非成するものであったのではないかと提えること ができる。

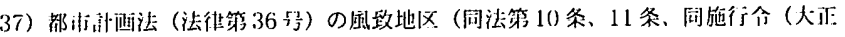

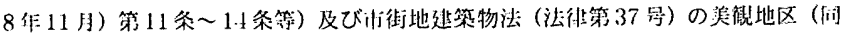

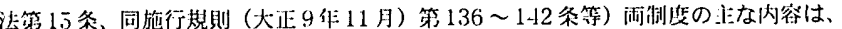

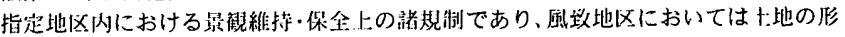

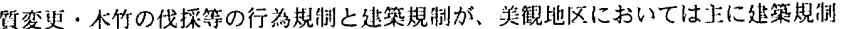

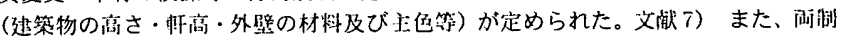

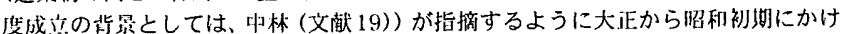

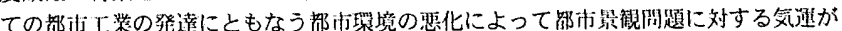
高まったことが第一にあげられる。しかし一方で、風致地区に関しては当初の目例と

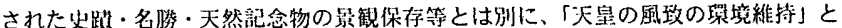
いった累なる目的が併祦しむしし初期の地区指定においては後者の方が少行してい

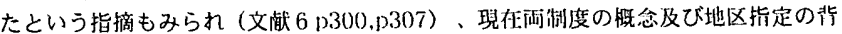
路については梯々な詳論がなされている。

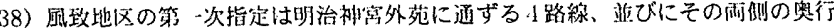

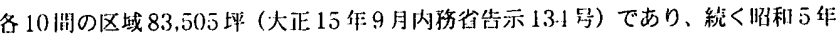

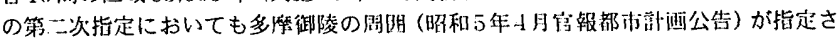
れており，同じく御料地に係わる土地の指定であった。一方、美観地区の第一回指定

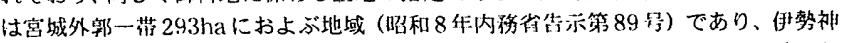
官のある宇治山田市も䧂和 1 年 10 月に美镀地区指定されている。結局、戦前にお いて美智地区指定がさ㧈た地域はわずかに 3 简所であり（もう一力所は大阪术の指 定)、数少ない敞颌の指定の山で御料地に俰わる地域が数多く指定された。文献 7) 39）例元ば文解 6)、文献 7)

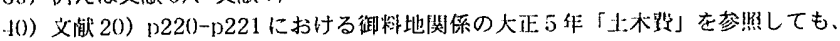

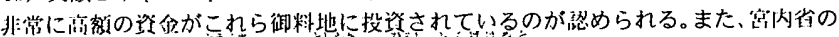

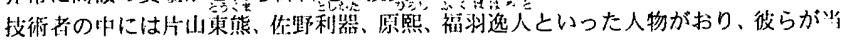

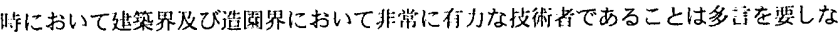

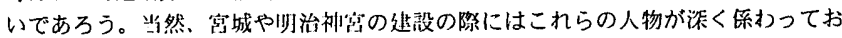

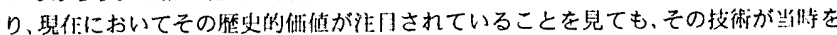
代装するものであったことは疑いの余地がない。

\section{文献}

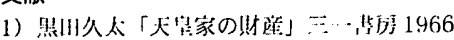

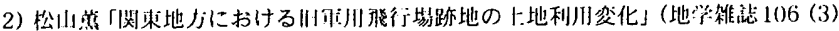
1997 p3:32-1)35.5)

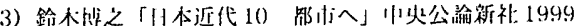

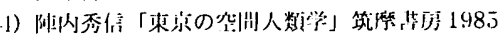

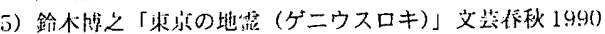

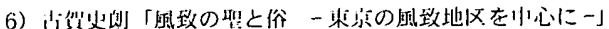

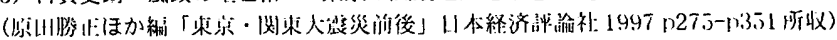

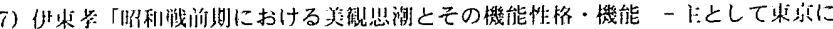

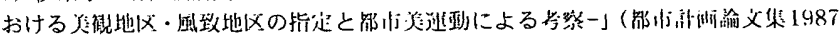
1029.5-1P:300)

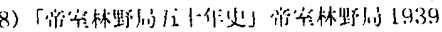

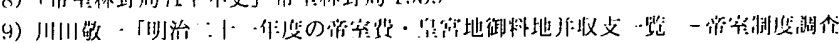

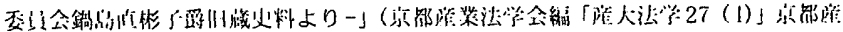

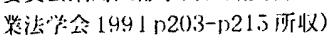

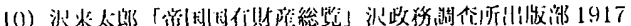

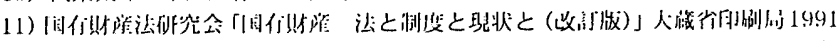

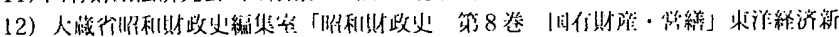
被补: 19.5

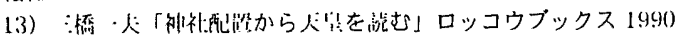

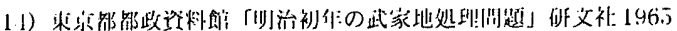

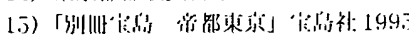

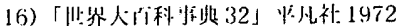

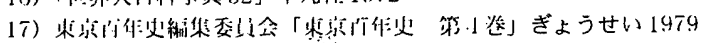

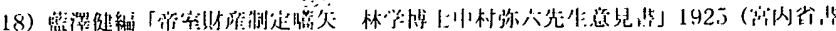
陵部河藏)

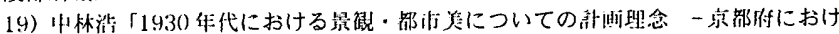

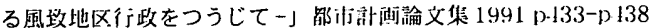

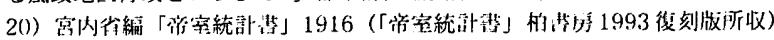

（2000年 4 月 10 日原稿受理，2000年10月19日採用決定 